\title{
The ovarian insulin-like growth factor system
}

\author{
J. M. Hammond*, J. S. Mondschein*, S. E. Samaras*, S. A. Smith* and \\ D. R. Hagen $\dagger$ \\ *Department of Medicine, Penn State University, Hershey, PA I7033, USA; and † Department of \\ Dairy and Animal Science, Penn State University, University Park, PA 16802, USA
}

Keywords: ovary; ovarian follicles; granulosa cells; growth factors; insulin-like growth factors

\section{Introduction}

The growth and development of the ovarian follicle entails a co-ordinated process of cell replication and differentiation during which the number of granulosa cells lining the follicle may increase dramatically and daughter cells emerge with a different complement of hormone receptors and steroidogenic enzymes. During the reproductive life of mammals these events are clearly entrained to the pituitary signals of the reproductive cycle. However, few follicles exposed to these signals reach the stage of ovulation. These physiological facts required ovarian physiologists to invoke autocrine or paracrine mechanisms long before these terms were developed and popularized. The definition of these mechanisms has emerged as one of the dominant topics in ovarian research in the past decade.

Numerous putative intraovarian regulators have been identified by these efforts. Among these, the ovarian growth factors have probably received the most attention. Peptide growth factors of several classes, e.g. insulin-like growth factors (IGFs), the epidermal growth factor (EGF)/transforming growth factor (TGF)- $\alpha$ family, TGF- $\beta$, fibroblast growth factors (FGFs) and the cytokines, interleukin-1 and tumour necrosis factor, have been found in the ovary and shown to be active on ovarian cells (reviewed by Hammond et al., 1988b; Adashi, 1989). Amongst the several classes of growth factors, data on the IGFs are the most comprehensive. In addition, the IGFs are the main focus of our own research efforts. Accordingly, we will concentrate on this system and on our own data in this review,

\section{Overview of the ovarian IGF system}

As depicted in Fig. 1 and reviewed below, IGFs are present and secreted in the ovary and are active on ovarian cells. In addition, detailed information is now available about the manner in which this system is interfaced with the hormonal signals of the reproductive cycle. Since gonadotrophins facilitate both the secretion and action of ovarian IGFs, these peptides constitute a possible local amplification system for gonadotrophin action which could materially enhance the likelihood of a follicle surviving to ovulation. These studies reflect the central theme in ovarian IGF research. In addition, there are questions which need to be addressed before a comprehensive understanding of this system can be achieved. These include the relative importance of IGF-I and II in ovarian physiology, and the role of the IGF binding proteins (BPs). Preliminary evidence suggests that each of these areas may be of substantial importance.

\section{Ovarian action of the IGFs}

The actions of IGF-I, IGF-II, and insulin in the ovary as well as other tissues can be mediated by the Type I IGF receptor, the structurally related insulin receptor, and/or the Type II IGF/mannose 


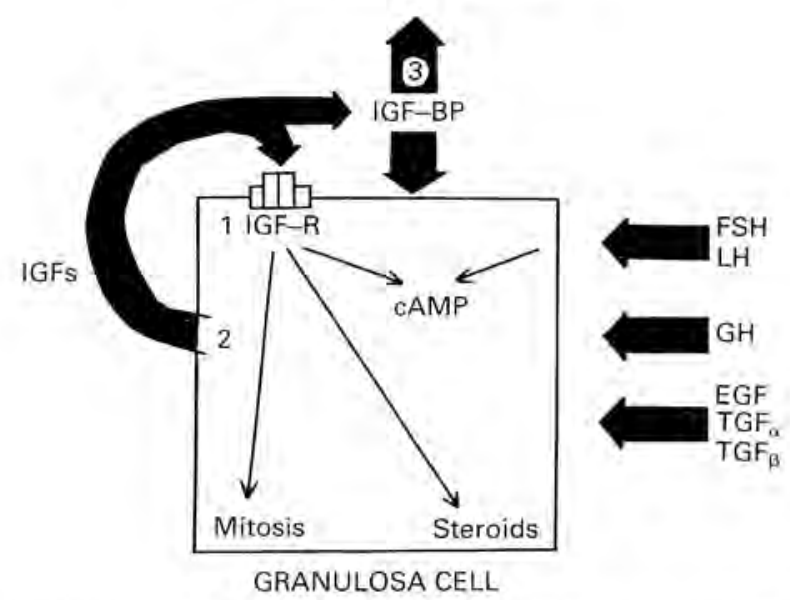

Fig. 1. Principal components of the ovarian IGF system: (1) receptor mediated IGF-action; (2) hormone-stimulated IGF secretion; (3) IGF-binding proteins (BPs).

6-phosphate binding site (Czeck, 1989). All three types of receptors have been demonstrated in ovary (Baranao \& Hammond, 1984; Poretsky et al,, 1985; Davoren et al., 1986). In the vast majority of instances, effects of the insulin-like peptides have shown the relative potencies typical of the Type 1 receptor, i.e. IGF-I $>$ IGF-II $>$ insulin. Type I receptors are inducible by gonadotrophins and gonadal steroids (Adashi et al., 1986; Veldhuis et al., 1986), and thus represent a potentially important control locus. After binding to cell surface receptors, the IGFs and/or insulin can stimulate either growth-related processes or cytodifferentiation of ovarian cells. The growth responses predominate when the insulin-like peptides are used alone or are combined with other growth factors, whereas, in the presence of gonadotrophins or cyclic AMP, cytodifferentiation predominates at the expense of cell replication (Hammond \& English, 1987; Hammond et al., 1989). A typical example of the mitogenic actions of the insulin-like peptides, and the interaction of these peptides with FSH and oestradiol is shown in Fig. 2.

Insulin and IGFs also enhance the differentiated function of both granulosa (below) and theca cells (Barbieri et al., 1986; Cara \& Rosenfield, 1988). With granulosa cells, the IGFs or insulin seem to be essential for optimal effects of FSH on all end points examined to date (reviewed by Adashi et al., 1985b; Hammond et al, 1988b). Specific points in the steroidogenic pathway enhanced by IGFs include internalization and processing of exogenous cholesterol and side chain cleavage (reviewed by Veldhuis, 1989) and aromatase (Adashi et al., 1985a; Davoren el al., I985; Veldhuis et al., 1985). Under our culture conditions (Baranao \& Hammond, 1984) in which micronutrients are heavily supplemented, the effects of IGFs on progesterone secretion are demonstrable only with gonadotrophins. In contrast, effects on steroidogenesis can be demonstrated in the absence of gonadotrophins under more stringent culture conditions (Veldhuis et al., 1985; Veldhuis, 1989). Irrespective of the culture conditions used, a synergistic interaction of gonadotrophins and IGFs has been observed (Fig. 3).

\section{Ovarian secretion of IGFs}

For the aforementioned actions of the IGFs to be mediated in an autocrine or paracrine fashion, it is necessary for them to be present and/or secreted in the ovary. This topic has been of particular interest to us, and our results have been confirmed and extended by other groups. With reference to ovarian IGF levels in vivo, our studies indicated that (1) IGFs were easily measurable in pig follicular fluid (Hammond et al., 1982, 1983, 1985); (2) IGF-II and IGF-I were both present (Hammond 


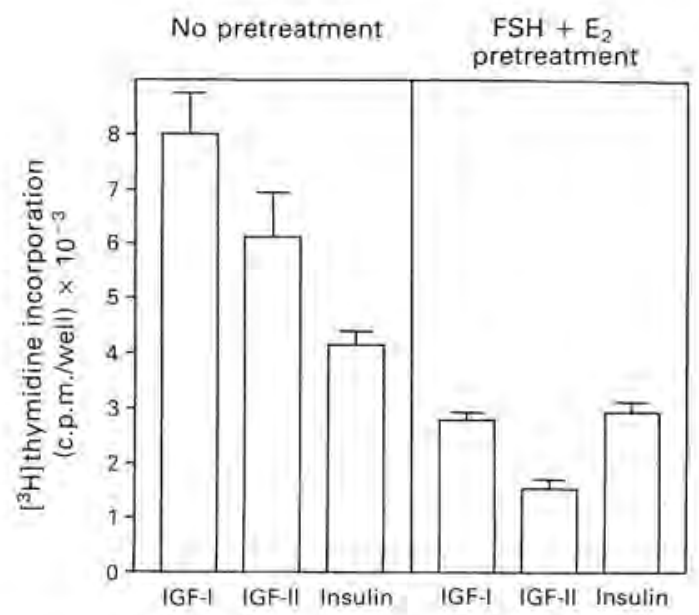

Fig. 2. Mitogenic response of granulosa cells to insulin-like peptides. Granulosa cells were cultured in highly supplemented serum-free medium for 3 days, growth arrested in defined medium for $24 \mathrm{~h}$, and challenged with the insulin-like peptides and [methyl- ${ }^{3} \mathrm{H}$ ] thymidine for $36 \mathrm{~h}$. The cultures indicated were treated additionally with oestradiol $\left(\mathrm{E}_{2}, 1 \mu \mathrm{g} / \mathrm{ml}\right)$ and FSH $(200 \mu \mathrm{g} / \mathrm{ml})$ for the duration of the experiment (from Hammond et al., 1989). The results are from a single experiment with 4 replicate cultures in each treatment group; variation within each treatment group is given by an s.e.m. bar.

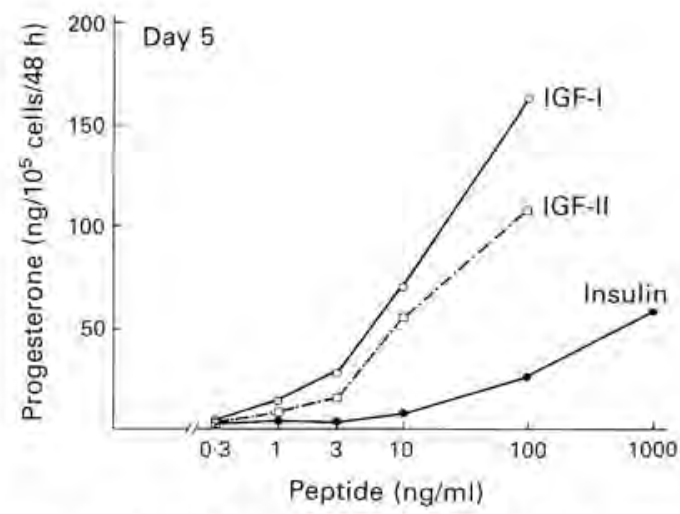

Fig. 3. Synergistic interaction of FSH and insulin-like peptides on steroidogenesis. Granulosa cells were cultured for 5 days in serum-free medium containing $200 \mathrm{ng} \mathrm{FSH} / \mathrm{ml}$, and the doses of insulin-like peptides indicated. In the absence of FSH, the steroidogenic response to the IGFs was not demonstrable (data not shown) (From Baranao \& Hammond, 1984.)

et al., 1985; Mondschein et al., 1988b); (3) the concentration of IGFs in follicular fluid increased during follicular growth (Hammond et al., 1985); and (4) the concentration of IGF-I in follicular fluid was increased by gonadotrophins (Hammond et al., 1988a), and growth hormone (Bryan et al., 1989). Related data on ovarian IGF-I levels in the rat and their stimulation by growth hormones have been developed through organ extractions by Davoren \& Hsueh (1986). In addition, high concentrations of IGF-II have been found in human follicular fluid (Ramasharma et al., 1986). Additional, more recent, studies of human (Eden et al., 1988) and bovine (Spicer et al., 1988) follicular fluid have also documented the presence of IGF-I and suggested changes as a function of follicular size. Finally, mRNA for IGF-I and/or II has been demonstrated in the ovary 
of the rat (Hernandez et al., 1989; Oliver et al., 1989), pig (S. E. Samaras \& J. M. Hammond, unpublished), and human (Voutilainen \& Miller, 1987).

Evidence concerning the secretion of IGFs by ovarian cells and its hormonal regulation has been provided more directly by studies with cultured granulosa cells of pigs and man. Our data with cells from poorly differentiated follicles indicated that IGF-I secretion predominated over IGF-II (Mondschein et al., 1988b), and that secretion of IGF-I could be enhanced by FSH, oestradiol, LH, growth hormone (Hsu \& Hammond, 1987a, b) (see Fig. 4), and EGF (Mondschein \& Hammond, 1988). In contrast, TGF- $\beta$ appeared to inhibit IGF-I secretion in vitro except at very low concentrations (Mondschein et al., 1988a). With these cells, gonadotrophin-responsive IGF secretion develops over several days in culture. More recent studies with granulosa cells from larger $(5-6 \mathrm{~mm})$ follicles have shown more active secretion of IGF-I earlier in culture and greater responsiveness to gonadotrophin; further such cells secrete IGF-II as well as IGF-1 (J. S. Mondschein \& J. M. Hammond, unpublished).

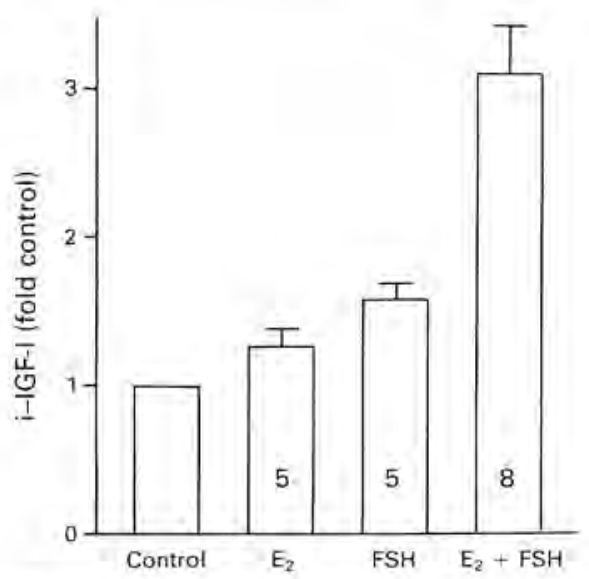

Fig. 4. Effects of oestradiol and FSH on immunoreactive (i) IGF-I secretion by cultured pig granulosa cells. Values are the mean \pm s.e.m. for the no. of experiments indicated. Values were normalized by cell counts and divided by control values in each experiment. Each value is significantly different from the others $(P<0.05,2$-way ANOVA). (Redrawn from Hsu \& Hammond, 1987a.)

In summary, our data with follicular fluid, granulosa cell-conditioned media, and analysis of ovarian mRNA levels, suggest that IGF-I and IGF-II are both synthesized in the pig ovary (Mondschein et al., 1988b; S. E. Samaras \& J. M. Hammond, unpublished). In the human, assays of the peptides and/or their mRNA suggest that the dominant ovarian IGF is IGF-II (Ramasharma \& Li, 1987; Voutilainen \& Miller, 1987). In contrast, hybridization data (Oliver et al., 1989; Hernandez et al., 1989) suggest that IGF-I is the dominant, if not the exclusive, ovarian IGF in the rat. The diversity of expression of these peptides in the ovary amongst species and under various experimental conditions is intriguing and somewhat unexpected. The relative importance of the two peptides as intraovarian regulators remains to be fully resolved.

\section{The role of IGF-binding proteins}

Our early studies of IGF levels in follicular fluid and granulosa cell-conditioned medium indicated that IGF-BPs were abundant in these samples (Hammond et al., 1982, 1985). In recent years, there has been an explosion of information about the IGF-BPs in the ovary and in other tissues. It is now possible to speculate that these proteins may be as important for ovarian regulation as the IGFs 
themselves. Briefly summarized, these studies have indicated that IGF-BPs are not simply present or absent, but represent a family of discrete gene products with variable tissue expression and physiological regulation and with the potential for diverse effects on IGF paracrine systems. Three of these proteins have now been cloned and sequenced (designated IGF-BP-1, -2, -3 in order of molecular size), and each of these is known to be secreted in the ovary (Seppala et al., 1984; Mondschein et al., 1989b).

We have examined the IGF-BPs in pig follicular fluid by "ligand blotting techniques and immunoprecipitation. IGF-BP-2 and -3, with apparent molecular weights of 34000 and $40000-$ 45000 respectively, are the major binding species in the pig ovary (Mondschein et al, 1989b). To date, we have not been able to identify conclusively IGF-BP-1 in the pig ovary by immunochemical or molecular techniques. However, a minor band which comigrates with human IGF-BP-1 is found in our samples (Mondschein et al., 1989b) and other workers have unequivocally demonstrated this binding protein in the human ovary (Seppala et al., 1984). There is at least one additional ovarian IGF-BP, with an apparent molecular weight of around 24000 , which is not recognized by any of our antibodies (Mondschein et al., 1989b).

The relative proportion of the several IGF-BPs differs in small and large preovulatory follicles (Mondschein et al., 1989b). Small, poorly differentiated, follicles contain higher concentrations of total IGF-BP activity than do those from large follicles, and higher concentrations of the low molecular weight IGF-BPs in particular. An immunoprecipitation study defining the relative proportion of IGF-BP-2 and -3 in large and small follicles is depicted in Fig. 5. When IGF-BPs were characterized in follicles from hormone-treated pigs (Samaras et al., 1990), we noted that PMSG caused a decrease in IGF-BP-2, whereas GH treatment was associated with a substantial increase in IGF-BP-2 and -3 .

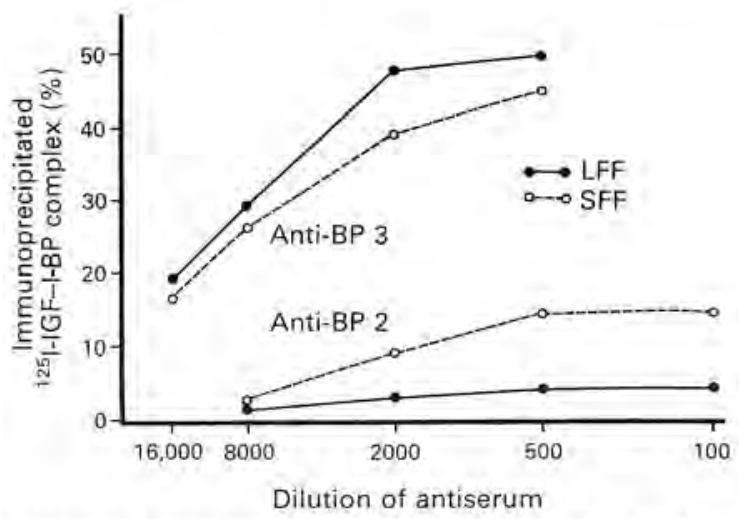

Fig. 5. Immunoprecipitation of IGF-BP-3 and IGF-BP-2 in follicular fluid of small (SFF) and large (LFF) follicles. IGF-BPs in follicular fluids from small $(1-3 \mathrm{~mm})$ and large $(6-8 \mathrm{~mm})$ pig follicles were exchange-labelled with ${ }^{125} \mathrm{I}$-labelled IGF-I at $4{ }^{\circ} \mathrm{C}$ and bound radioactivity precipitated with antibodies to pig IGF-BP-3 and IGF-BP-2.

Each of the binding proteins detectable in follicular fluid can also be demonstrated in granulosa cell-conditioned medium. The amount and type of IGF-BP secreted is dependent on the follicular origin of the cultured granulosa cells, time in culture, and treatment with hormones and growth factors (Mondschein et al., 1989b; Mondschein \& Hammond, 1990). The principal findings of this series of studies were: (1) granulosa cells from large follicles secreted 10-20-fold higher levels of IGF-BPs than did those from small follicles, although the profile on the IGF-BPs on ligand blots was similar; (2) in both types of cultures, there was a shift from high molecular weight (principally IGF-BP-3) to low molecular weight (IGF-BP-2 and smaller species) with time in culture; (3) FSH inhibited and GH stimulated the production of IGF-BP-2 and/or IGF-BP-3; (4) EGF stimulated 
and TGF- $\beta$ inhibited the production of IGF-BP-2 and -3. Of particular interest to our understanding of the intrafollicular IGF system are the divergent effects of the principal hormonal stimulators of IGF secretion; FSH inhibits whereas GH stimulates the production of IGF-BPs. These findings are illustrated in Fig. 6.

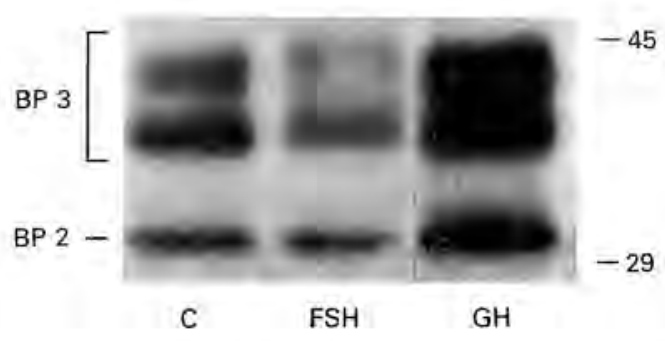

Fig. 6. Ligand blot of IGF-BP activity in media conditioned by granulosa cells from $5-6 \mathrm{~mm}$ pig follicles. Cells were cultured for 3 days in serum-free medium in the presence or absence of FSH $(200 \mathrm{mg} / \mathrm{ml}$ or $\mathrm{GH}(300 \mathrm{mg} / \mathrm{ml})$. Then $10 \mu \mathrm{l}$ medium were electrophoresed on $10 \%$ SDS polyacrylamide gels under non-reducing conditions. The gels were electroblotted onto nitrocellulose; the blots were probed with ${ }^{125}$ I-labelled IGF-II and analysed by autoradiography.

In understanding the importance of these observations for ovarian regulation, it is necessary to summarize briefly the current thinking on the biological activities of the IGF-BPs. In the first instance, IGF-BPs could cause an apparent increase in IGF levels by cross-reacting in RIAs for the IGFs themselves. Additionally, the IGF-BPs could increase local levels of the ligands by sequestering IGFs. Thus, total IGF levels could be increased by an increase in IGF-BPs even if local IGF production were constant. This phenomenon might produce a discrepancy between IGF levels and IGF bioactivity. Ui et al. (1989) purified an FSH action inhibitor from pig follicular fluid which was discovered (after sequencing) to be IGF-BP-3. This IGF-BP presumably inhibits FSH action by binding and consequently blocking the effects of ovarian IGFs.

In addition to negative effects of IGF action, the IGF-BPs can enhance IGF effects in some circumstances. These positive effects, which have yet to be demonstrated in the ovary, may be mediated by slow prolonged release of the IGFs onto their target cells (Blum et al , 1988), or in the case of IGF-BP-1 and -2, interaction of the BPs themselves with the target cells through binding of a specific 'RGD' tripeptide sequence to fibronectin-type receptors (Busby et al., 1988). In addition, a 'multimerization reaction' of IGF-BP-1 may be involved in a synergistic effect on IGF action (Busby et al., 1989). While it may be some time before the ovarian effects of the IGF-BPs are thoroughly understood, the results to date suggest that these effects will be important.

\section{A tentative physiological construct}

The studies reviewed above indicate clearly that ovarian cells secrete and respond to IGFs. Further, we and others have shown that this local system is interfaced with pituitary gonadotrophins through mechanisms of enhanced growth factor secretion, mutual receptor induction, and synergistic steroidogenic interaction. Collectively, these data allow a strong circumstantial case to be made for the IGFs as regulators of follicle development. However, this evidence falls short of compelling proof of an obligatory role for IGFs in these processes in vivo. The most direct evidence 
to date concerning the importance of the IGFs in the follicle has been provided by antibody blocking studies conducted in our laboratory (Mondschein et al., 1989a) and presented in part in Table 1. These studies have shown that the IGFs are an important component of the steroidogenic milieu in the preovulatory pig follicle.

Table 1. Effects of monoclonal antibody to insulin-like growth factor-1 on progesterone production and cell number in cultures of immature granulosa cells treated with follicular fluid from large and small pig follicles (from Mondschein et al., 1989a)

\begin{tabular}{lccc}
\hline Follicle & Antibody & $\begin{array}{c}\text { Progesterone production } \\
\left(\mu \mathrm{g} / 10^{6} \text { cells } / 48 \mathrm{~h}\right)\end{array}$ & $\begin{array}{c}\text { Cell no } \\
\left(10^{-5} \text { cells }\right)\end{array}$ \\
\hline Large & - & $2 \cdot 093 \pm 0.579$ & $4.87 \pm 0.26$ \\
Small & + & $0.827 \pm 0.228^{*}$ & $4.34 \pm 0.23^{*}$ \\
& - & $0.441 \pm 0.101$ & $3.59 \pm 0 \cdot 32$ \\
& + & $0.428 \pm 0.083$ & $3.35 \pm 0.25$ \\
\hline
\end{tabular}

Values are the means \pm s.e. for 9 separate experiments for large follicles and 3 separate experiments for small follicles and each experiment used 4-6 cultures per treatment.

$* P<0.05$ compared with no antibody.

Building on observations of this type, clinicians in several countries have now attempted to increase intrafollicular IGF levels during ovulation induction by short-term administration of GH (Homburg et al., 1988; Blumenfeld \& Lunenfeld, 1989). The results suggest that an increase in sensitivity to exogenous gonadotrophins occurs. Further, the IGF system has now been examined in several animal models of genetic increases in fecundity (Zavy et al., 1989; Echternkamp et al., 1990). These data indicate an increase in ovarian and/or circulating IGFs in many, but not all, of these animal breeds. Collectively, these clinical and physiological studies provide additional support for a role for the ovarian IGF system in vivo.

However, there are several physiological observations which do not readily fit this model. Understanding of these results will also be important to the development of an accurate picture of the ovarian IGF system. In our studies of reproductive effects of growth-promoting doses of GH administered chronically to pigs in vivo, we uniformly induced a substantial increase in intraovarian IGF-I levels (Bryan et al., 1989; Samaras et al., 1990). However, such treatment programmes have not resulted in a uniform increase in ovarian steroidogenesis or ovulation rate. In fact, some significant inhibitory effects have been observed (Bryan et al., 1989; Hagen et al., 1990). Related inhibitory actions of $\mathrm{GH}$ on ovarian function in pigs have been encountered by other workers (Kirkwood et al., 1988). These studies suggest that increased intrafollicular IGF levels are not sufficient to affect ovarian follicular development and steroidogenesis. A similar conclusion was suggested by a comparison of the actions of fluid from small and large follicles in the experimental paradigms illustrated in Table 1. In contrast to the steroidogenic actions of fluid from highly differentiated follicles, fluid from immature follicles, which contains substantial quantities of IGF-I and II (Hammond et al., 1985), was not steroidogenic, and the effects of the anti-IGF monoclonal antibody were negligible.

These apparent discrepancies are not completely understood, but a number of possible explanations can be proposed. (1) Timely activation of the intrafollicular IGF system by cyclic gonadotrophin release may be crucial for its proper operation. (2) The dominant activity of the IGFs may depend on the concomitant presence of other ovarian growth factors and/or gonadotrophins. The IGF-gonadotrophin interaction has been explored throughout this paper. In addition, we have suggested (Hammond et al., 1989) that earlier in the life of the follicle an interaction between EGF/TGF $\alpha$ and the IGFs might predominate. Such an interaction could promote follicle growth while restraining premature steroidogenesis. (3) The levels of inhibitory IGF-BPs may determine 
the set point of the IGF response system. This hypothesis could partly explain the divergence in the effects of FSH and chronic GH treatment on ovarian function as well as the apparent differences in 'bioactivity' of IGFs in large and small follicles.

This research was supported by grants from the National Institutes of Health (RO1 HD24536) and the competitive grants program, US Department of Agriculture. We thank Dr J. J. Van Wyk, Dr Matthew Rechler, Dr George Veomette and Dr Terry Etherton for antibodies; Mrs Sandra Canning for technical support; and Mrs Carrie Leitzell for secretarial assistance.

\section{References}

Adashi, E.Y. (1989) Editorial Cytokine-mediated regulation of ovarian function: encounters of a third kind, Endocrinology 124, 2043-2045.

Adashi, E.Y., Resnick, C.E., Brodie, A.M.H., Svoboda, M.E. \& Van Wyk, J.J. (1985a) Somatomedin-Cmediated potentiation of follicle-stimulating hormone-induced aromatase activity of cultured rat granulosa cells. Endocrinology 117, 2313-2320.

Adashi, E.Y., Resnick, C.E., D'Ercole, A.J., Svoboda, M.E. \& Van Wyk, J.J. (1985b) Insulin-like growth factors as intraovarian regulators of granulosa cell growth and function. Endocrine. Rev. 6, 400-420.

Adashi, E.Y., Resnick, C.E., Svoboda, M.E. \& Van Wyk, J.J. (1986) Follicle-stimulating hormone enhances somatomedin $\mathrm{C}$ binding to cultured rat granulosa cells. J. biol, Chem. 261, 3923-3926.

Baranao, J.L.S. \& Hammond, J.M. (1984) Comparative effects of insulin and insulin-like growth factors on DNA synthesis and differentiation of porcine granulosa cells. Biochem. Biophys. Res. Commun. 124, 484-490.

Barbieri, R.L., Makris, A., Randall, R.W., Daniels, G., Kistner, R.W. \& Ryan, K.J. (1986) Insulin stimulates androgen accumulation in incubations of ovarian stroma obtained from women with hyperandrogenism. J. clin. Endocr. Metab. 62, 904-910.

Blum, W.F., Jenne, E.W., Reppin, F., Kietzmann, K., Ranke, M.E. \& Bierich, J.R. (1988) Insulin-like growth factor 1 (IGF-I)-binding protein complex is a better mitogen than free IGF-I. Endocrinology 125, $766-772$.

Blumenfeld, Z. \& Lunenfeld, B, (1989) The potentiating effect of growth hormone on follicle stimulation with human menopausal gonadotropin in a panhypopituitary patient. Fert. Steril. 52, 328-331.

Bryan, K.A., Hammond, J.M., Canning, S., Mondschein, J.S., Carbaugh, E., Clark, A.M. \& Hagen, D.R. (1989) Reproductive and growth responses of gilts to exogenous porcine pituitary growth hormone. $J$. Anim. Sci. 67, 196-205.

Busby, W.H., Jr, Klapper, D.G. \& Clemmons, D.R. (1988) Purification of a 31,000-dalton insulin-like growth factor binding protein from human amniotic fluid. J. biol. Chem. 263, 14203-14210.

Busby, W.H., Hossenlopp, P., Binoux, M. \& Clemmons, D.R. (1989) Purified preparations of the amniotic fluid-derived insulin-like growth factor-binding protein contain multimeric forms that are biologically active. Endocrinology 125, $773-778$.

Cara, J.F, \& Rosenfield, R.L. (1988) Insulin-like growth factor $I$ and insulin potentiate luteinizing hormone- induced androgen synthesis by rat ovarian thecalinterstitial cells. Endocrinology 123, 733-739.

Czech, M.P. (1989) Signal transmission by the insulinlike growth factors. Cell 59, 235-238.

Davoren, J.B. \& Hsueh, A.J.W. (1986) Growth hormone increases ovarian levels of immunoreactive somatomedin $\mathrm{C}$ /insulin-like growth factor $\mathrm{I}$ in vivo. Endocrinology 118, 888-890.

Davoren, J.B., Hsueh, A.J.W. \& Li, C.H. (1985) Somatomedin $\mathrm{C}$ augments FSH-induced differentiation of cultured rát granulosa cells. Am. J. Physiol, 249, E26-E33.

Davoren, J.B., Kasson, B.G., Li, C.H. \& Hsueh, A.J.W. (1986) Specific insulin-like growth factor (IGF)l- and II-binding sites on rat granulosa cells: Relation to IGF action. Endocrinology 119, 2155-2162.

Echternkamp, S.E., Spicer, L.J., Gregory, K.E., Canning, S.F. \& Hammond, J.M. (1990) Concentrations of insulin-like growth factor-I in blood and ovarian follicular fluid of cattle selected for twins. Biol. Reprod. 43, 8-14.

Eden, J.A., Jones, J., Carter, G.D. \& Alaghband-Zadeh, J. (1988) A comparison of follicular fluid levels of insulin-like growth factor-I in normal dominant and cohort follicles, polycystic and multicystic ovaries. Clin. Endocrinol. 29, 327-336.

Hagen, D.R., Bryan, K.A., Clark, A.M., Graboski, R.A. \& Hammond, J.M. (1990) Effect of duration of treatment with growth hormone (GH) and pregnant mare serum gonadotropin (PMSG) challenge on growth factors and ovarian steroids in gilts. Biol. Reprod. 42 Suppl. 1, 155, Abstr. 344.

Hammond, J.M. \& English, H.F. (1987) Regulation of deoxyribonucleic acid synthesis in cultured porcine granulosa cells by growth factors and hormones. Endierinology 120, $1039-1046$.

Hammond, J.M., Veldhuis, J.D., Seale, T.W. \& Rechler, M.M. (1982) Intraovarian regulation of granulosacell replication. In Intraovarian Control Mechanisms. pp. 341-356. Eds C. P. Channing \& S. J. Segal. Plenum. New York.

Hammond, J.M., Yoshida, K., Veldhuis, J.D., Rechler. M.M. \& Knight, A.B. (1983) Intrafollicular role of somatomedins: Comparison with eflects of insulin. In Factors Regulating Ovarian Function, pp. 197-201. Eds G. S. Greenwald \& P. F. Terranova. Raven Press, New York.

Hammond, J.M., Baranao, J.L.S., Skaleris, D., Knight, A.B., Romanus, J.A. \& Rechler, M.M. (1985) Production of insulin-like growth factors by ovarian granulosa cells. Endocrinology 117, 2553-2555. 
Hammond, J.M., Hsu, C-J., Klindt, J., Tsang, B.K. \& Downey, B.R. (1988a) Gonadotropins increase concentrations of immunoreactive insulin-like growth factor-I in porcine follicular fluid in vivo. Biol. Reprod. 38, 304-308.

Hammond, J.M., Hsu, C.-J., Mondschein, J.S. \& Canning, S.F. (1988b) Paracrine and autocrine functions of growth factors in the ovarian follicle. J. Anim. Sci. 66, 21-31.

Hammond, J.M., Mondschein, J.S. \& Canning, S.F. (1989) Insulin-like growth factors (IGFs) as autocrine/ paracrine regulators in the porcine ovarian follicle. In Growth Factors and the Ovary, pp. 107-120. Ed. A. N. Hirshfield. Plenum Press, New York.

Hernandez, E.R., Roberts, C. T., Jr, LeRoith, D. \& Adashi, E.Y. (1989) Rat ovarian insulin-like growth factor I (IGF-I) gene expression is granulosa cellselective: 5'-untranslated mRNA variant representation and hormonal regulation. Endocrinology 125 , $572-574$

Homburg, R., Eshel, A., Abdalla, H.I. \& Jacobs, H.S. (1988) Growth hormone facilitates ovulation inducton by gonadotrophins. Clin. Endocrinol. 29, $113-117$

Hsu, C.-J. \& Hammond, J.M. (1987a) Gonadotropins and estradiol stimulate immunoreactive insulin-like growth factor-I production by porcine granulosa cells in vitro. Endocrinology 120, 198-207.

Hsu, C.-J. \& Hammond, J.M. (1987b) Concomitant effects of growth hormone on secretion of insulin-like growth factor-I and progesterone by cultured porcine granulosa cells. Endocrinology 121, 1343-1348.

Kirkwood, R.N., Thacker, P.A., Korchinski, R.S. \& Laarveld B. (1988) The influence of exogenous pituitary growth hormone on the ovulatory response to $\mathrm{PMSG}$ and $\mathrm{hCG}$ and the $\mathrm{LH}$ response to estradiol benzoate in prepubertal gilts, Dom. Anim. Endocrinol. 5, 317-322.

Mondschein, J.S. \& Hammond, J.M. (1988) Growth factors regulate immunoreactive insulin-like growth factor-I production by cultured porcine granulosa cells. Endocrinology 123, 463-468.

Mondschein, J.S. \& Hammond, J.M. (1990) Production of insulin-like growth factor binding proteins by porcine granulosa cells in culture. Program of the Endocrine Society, Abstr. 977.

Mondschein, J.S., Canning, S.F. \& Hammond, J.M. (1988a) Effects of transforming growth factor beta on the production of immunoreactive insulin-like growth factor-I and progesterone and ${ }^{3} \mathrm{H}$-thymidine incorporation in porcine granulosa cell cultures. Endocrinology 123, 1970-1976.

Mondschein, J.S., Hammond, J.M. \& Canning, S.F. (1988b) Profiles of immunoreactive (i) insulinlike growth factors (IGFs) - I and - II in porcine follicular fluid (FF) and granulosa cell conditioned medium (GCCM). Biol. Reprod., (Suppl. 1), p. 191, abstr.

Mondschein, J.S., Canning, S.F., Miller, D.Q. \& Hammond, J.M. (1989a) Insulin-like growth factors (IGFs) as autocrine/paracrine regulators of granulosa cell differentiation and growth: studies with a neutralizing monoclonal antibody to IGF-1. Biol. Reprod. 40, 79-85
Mondschein, J.S., Hammond, J.M. \& Etheston, T. (1989b) Studies of insulin-like growth factor (IGF) binding proteins (BPs) in porcine ovary. Program of the Endocrine Society, Abstr. 877.

Oliver, J.E., Aitman, T.J., Powell, J.F., Wilson, C.A. \& Clayton, R.N. (1989) Insulin-like growth factor I gene expression in the rat ovary is confined to the granulosa cells of developing follicles. Endocrinology 124, 2671-2679.

Poretsky, L., Grigorescu, F., Seibel, M., Moses, A.C. \& Flier, J.S. (1985) Distribution and characterization of insulin and insulin-like growth factor-I receptors in normal human ovary. J. clin. Endocr. Metab. 61, $728-734$

Ramasharma, K. \& Li, C.H. (1987) Human pituitary and placental hormones control human insulin-like growth factor II secretion in human granulosa cells. Proc, nain. Acad.Sci. US.4 84, 2643-2647.

Ramasharma, K., Cabrera, C.M. \& Li, C.H. (1986) Identification of insulin-like growth factor-II in human seminal and follicular fluids. Biochem. Biophys. Res. Commun. 140, 536-542.

Samaras, S.E., Mondschein, J.S., Bryan, K., Hagen, D. \& Hammond, J.M. (1990) Growth hormone effects on ovarian function in gilts: changes in insulin-like growth factors and their binding proteins. Biol. Reprod. 42 (Suppl. 1), 126, Abstr. 256.

Seppala, M.W.T., Wahlstrom, T., Koskimies, A.I., Tenhunen, A., Rutanen, E.-M., Koistinen, R., Huhtaniemi, I., Bohn, H. \& Stenman, U.-H. (1984) Human preovulatory follicular fluid, luteinized cells of hyperstimulated preovulatory follicles, and corpus luteum contain placental protein 12. J. clin. Endocr. Metab. 58, 505-510.

Spicer, L.J., Echternkamp, S.E., Canning, S.F. \& Hammond, J.M. (1988) Relationship between concentrations of immunoreactive insulin-like growth factor-I in follicular fluid and various biochemical markers of differentiation in bovine antral follicles: Biol. Reprod. 39, 573-580.

Ui, M., Shimonaka, M., Shimasaki, S. \& Ling, N. (1989) An insulin-like growth factor-binding protein in ovarian follicular fluid blocks folliclestimulating hormone-stimulated steroid production by ovarian granulosa cells. Endocrinology 125, 912 916.

Veldhuis, J.D. (1989) Regulatory actions of the insulinlike growth factor, IGF-I (somatomedin-C), on sterol metabolism by ovarian cells. In Growth Factors and the Ovary, pp. 121-130. Ed. A. N. Hirshfield. Plenum Press, New York.

Veldhuis, J.D., Demers, L.M., Garmey, J., Juchter, D. \& Azimi, P. (1985) A role for somatomedin C as a differentiating hormone and amplifier of hormone action on ovarian cells: Studies with synthetically pure human somatomedin $\mathrm{C}$ and swine granulosa cells. Biochem. Biophys. Res. Commun. 130, 234-240.

Veldhuis, J.D., Rodgers, R.F., Furlanetto, R.W., Azimi, P., Juchter, D. \& Garmey, J. (1986) Synergistic actions of estradiol and the insulin-like growth factor somatomedin-C on swine ovarian (granulosa) cells. Endocrinology 119, 530-538. 
Voutilainen, R. \& Miller, W.L. (1987) Coordinate tropic hormone regulation of mRNAs for insulin-like growth factor II and the cholesterol side-chain-cleavage enzyme P450ssc, in human steroidogenic tissues. Proc. natn. Acad. Sci. USA 84, 1590-1594.
Zavy, M.T., Spicer, L.J. \& Von Tungeln, D.L. (1989) Secretion of insulin-like growth factor- $\mathrm{I}$ is associated with ovulation rate in sheep. Program of the Endocrime Soc Abstr. 1344. 